\title{
Analgesia de Parto em Paciente Portadora de Deficiência de Proteína S. Relato de Caso *
}

\author{
Labor Analgesia in Protein S Deficient Patient. Case Report
}

Renato Mestriner Stocche, TSA ${ }^{1}$; Luis Vicente Garcia, TSA ${ }^{2}$; Marlene Paulino dos Reis ${ }^{3}$; Jyrson Guilherme Klamt, TSA ${ }^{2}$

\author{
RESUMO \\ Stocche RM, Garcia LV, Reis MP, Klamt JG - Analgesia de Parto \\ em Paciente Portadora de Deficiência de Proteína S. Relato de \\ Caso
}

\begin{abstract}
JUSTIFICATIVA E OBJETIVOS: Na deficiência de proteína S, uma glicoproteína com atividade anticoagulante, o risco de eventos tromboembólicos está aumentado. O objetivo deste relato é abordar o manuseio anestésico em paciente obstétrica portadora desta deficiência.
\end{abstract}

RELATO DO CASO: Paciente com deficiência de proteína S, com 25 semanas de gestação, apresentou os seguintes resultados de exames: INR =0,9, TTPA $=32 \mathrm{~s}$ (controle 25,6), proteína $S=35 \%$ (normal $=70 \%$ a $130 \%)$. Nos dois últimos trimestres de gravidez, fez uso de até 12000 U de heparina, cada 8 horas. Com 38 semanas, foi internada em trabalho de parto. Decorridas 8 horas da interrupção da heparina, já com TTPA 25, 8 s (controle 27,8 s), realizou-se anestesia peridural injetando-se $6 \mathrm{ml}$ de bupivacaína a 0,2\% e fentanil $(20 \mu \mathrm{g})$, seguido de infusão contínua. O tempo de infusão foi de 5 horas com dose total de $40 \mathrm{mg}$ de bupivacaína. Não houve intercorrências e, 1 hora após a retirada do cateter, foi reiniciada heparina, por via subcutânea, 10.000 UI, a cada 12 horas. A mãe e o recém-nascido evoluíram bem, recebendo alta no terceiro dia do pós-parto.

CONCLUSÕES: Grávidas com deficiência de proteína $S$ devem receber anticoagulantes com o objetivo de manter o TTPA 2 vezes o valor controle. A heparina, por não atravessar a barreira placentária, é o anticoagulante de eleição em obstetrícia. O bloqueio pode ser realizado respeitando um tempo mínimo entre 4 a 6 horas entre a última dose de heparina e a realização da punção lombar, desde que os exames apresentem parâmetros de normalidade. Entretanto, nestes casos, a analgesia peridural pode auxiliar na profilaxia de eventos tromboembólicos.

Unitermos: ANALGESIA, Obstétrica: parto; DOENÇA: deficiência de proteína S; TÉCNICAS ANESTÉSICAS, Regional: peridural

\author{
SUMMARY \\ Stocche RM, Garcia LV, Reis MP, Klamt JG - Labor Analgesia in \\ Protein S Deficient Patient. Case Report
}

BACKGROUND AND OBJECTIVES: Deficiency in protein S, which is a glycoprotein with anticoagulant activity, increases the risk for thromboembolic events. This report aimed at addressing anesthetic management of protein $S$ deficient obstetric patient.

CASE REPORT: Protein S deficient patient, at 25 weeks gestation, presented the following lab results: INR $=0.9$, TTPA $=32 \mathrm{~s}$ (control 25.6), protein $S=35 \%$ (normal $=70 \%$ to $130 \%$ ). In the last three gestation quarters she has received up to 12,000 IU heparin every 8 hours. With 38 weeks, she was admitted in labor. After 8 uninterrupted heparin hours, already with TTPA of 25.8 s (control 27.8 s) epidural anesthesia was induced with 6 $\mathrm{ml}$ of $0.2 \%$ bupivacaine and fentanyl $(20 \mu \mathrm{g})$, followed by continuous infusion. Infusion time was 5 hours with total $40 \mathrm{mg}$ bupivacaine dose. There have been no intercurrences and 1 hour after catheter removal, subcutaneous 10,000 IU heparin were restarted at 12-hour intervals. Patient and neonate evolved well and were discharged 3 days later.

CONCLUSIONS: Protein S deficient pregnant patients should receive anticoagulants to maintain TTPA twice the control value. Heparin, for not crossing placental barrier, is the anticoagulant of choice in obstetrics. Blockade may be induced respecting a minimum period of 4 to 6 hours between last heparin dose and lumbar puncture, provided lab tests are within normal ranges. In these cases, however, epidural analgesia may help in preventing thromboembolic events.

Key Words: ANALGESIA, Obstetric: labor; ANESTHETIC TECHNIQUES, Regional: epidural; DISEASES: protein $S$ deficiency

\section{INTRODUÇÃO}

A proteína S é uma glicoproteína sérica, dependente da Avitamina $\mathrm{K}$, que age como co-fator da proteína $\mathrm{C}$, a qual tem atividade anticoagulante ${ }^{1}$. A proteína $C$ exerce sua função inativando os fatores Va e VIIla da cascata de coagulação ${ }^{2}$. Este efeito anticoagulante regulador apresenta-se como mecanismo fisiológico anti-trombótico. Portando, a deficiência de proteína $S$, bem como da proteína $C$, são fatores de risco para eventos tromboembólicos e são atualmente classificados como doenças trombofilicas ${ }^{3}$.

A deficiência de proteína $S$ pode ser de origem hereditária, com padrão variado de alterações gênicas, ou adquirida ${ }^{4}$. Estados fisiológicos como a gravidez podem diminuir os níveis plasmáticos de proteína $S^{5}$. Várias doenças têm sido relacionadas à deficiência, tais como mieloma múltiplo ${ }^{6}$, infecção por vírus $\mathrm{HIV}^{7}$ e da varicela ${ }^{8}$, lúpus eritematoso sistêmico ${ }^{9}$, síndrome nefrótica ${ }^{10}$, dentre outras.

Em geral, os pacientes portadores de deficiência de proteína $S$ apresentam quadro clínico de trombose venosa ou arterial 
reincidentes ${ }^{11}$, em pacientes jovens ${ }^{12}$, sem fator predisponente ou em locais pouco comuns para a idade ${ }^{13}$. Na gravidez podem ocorrer aborto de repetição, descolamento de placenta, óbito intra-útero e baixo peso para idade gestacional, todos relacionados aos múltiplos infartos placentários ${ }^{14}$. Suspeita-se do diagnóstico devido à história de eventos tromboembólicos, história familiar ou história de interrupções abruptas de gravidez ${ }^{15}$. A confirmação é feita através de dosagem sérica ${ }^{16}$

Este relato tem a intenção de abordar os aspectos de manuseio da coagulação, dos riscos de tromboembolismo e dos riscos de hematoma espinhal relacionados à técnica de analgesia de parto em paciente portadora de deficiência hereditária de proteína S.

\section{RELATO DO CASO}

Paciente de 29 anos de idade, com deficiência de proteína S diagnosticada, clínica e laboratorialmente, 2 anos após ter apresentado dois episódios de trombose venosa profunda de membros inferiores.

A partir de $25^{a}$ semana de gestação foi encaminhada para acompanhamento no ambulatório de pré-natal de alto risco e de hematologia, quando apresentou os seguintes resultados de exames: TP $=0,9$ segundos, INR $=0,9$, TTPA $=32$ segundos (controle 25,6), TT = 8 segundos (controle 9,5), Proteína $\mathrm{S}=35 \%$ (normal $=70 \%$ a $130 \%$ ), Antitrombina III $=90 \%$ (nor$\mathrm{mal}=70 \%$ a $130 \%$ ), Fibrinogênio $=290 \mathrm{mg} / \mathrm{dl}$ (normal $=200 \mathrm{a}$ 400 ), Proteína $C=73 \%$ (normal $=70 \%$ a $130 \%$ ). Apartir do início do acompanhamento pré-natal, fez uso de heparina de 10.000 a 12.000 UI, por via subcutânea cada 12 ou 8 horas, com o intuito de manter INR próximo a 2 (Tabela I). Os exames laboratoriais hematológicos com dosagem de hemoglobina, hematócrito e outros permaneceram dentro da normalidade durante toda a gravidez e no período pós-parto imediato.
Agravidez transcorreu sem eventos graves e com a coagulopatia controlada. Foram realizados quatro exames ultrassonográficos, que não evidenciaram anomalias fetais nem placentárias.

Com 38 semanas e 6 dias de amenorréia, a paciente foi internada em trabalho de parto com $4 \mathrm{~cm}$ de dilatação e dinâmica de 2 contrações em 10 minutos. Após admissão hospitalar, o caso foi discutido com hematologista, anestesiologista e obstetra, quando foi decidido interromper a heparina e administrar protamina, se necessário. Optou-se pelo parto por via vaginal com analgesia de parto precoce por via peridural. Após exame prévio de tempo de coagulação ativada com resultado de 105 segundos e TPPA próximo do controle $(25,6$ segundos), foi realizada punção peridural com introdução de cateter. Foram administrados inicialmente $6 \mathrm{ml}$ de bupivacaína a $0,2 \%$ associado a $20 \mu \mathrm{g}$ de fentanil, seguidos de infusão contínua de bupivacaína a $0,2 \%$ e fentanil $\left(1 \mu \mathrm{g} \cdot \mathrm{ml}^{-1}\right)$ de 2 a 6 $\mathrm{ml} . \mathrm{h}^{-1}$ até o término do segundo estágio do trabalho de parto, não havendo necessidade de dose suplementar. O parto foi feito com ajuda de fórceps, após decorrida 1 hora da dilatação total do colo uterino. O tempo total de infusão foi de 5 horas, com dose total de $40 \mathrm{mg}$ de bupivacaína e $34 \mu \mathrm{g}$ de fentanil. Imediatamente após o nascimento, foi retirado o cateter peridural e, após 1 hora, reiniciada a heparina por via subcutânea $10.000 \mathrm{U}$ cada 12 horas. A paciente e o recém-nascido evoluíram no pós-operatório sem complicações e receberam alta no segundo dia do pós-parto.

\section{DISCUSSÃo}

A deficiência de proteína $S$, associada a hipercoagulabilidade gestacional e ao estresse do trabalho de parto, aumenta muito o risco de trombose intravascular durante a gravidez e no período peri-parto. Portanto, a profilaxia de tromboembolismo faz-se necessária ${ }^{14,15}$. O uso da heparina proporciona menor risco para o feto do que os cumarínicos, e deve ser utilizada durante toda a gravidez e no pós-parto imediato. De acordo com a literatura, neste caso, o TTPA foi mantido o do-

Tabela I - Exames de Controle de Heparinização, TTPA em Segundos, Dose de Heparina em Unidades Internacionais, Posologia em Horas

\begin{tabular}{|c|c|c|c|c|}
\hline Tempo de Amenorréia & TTPA Controle & TTPA Paciente & Dose de Heparina & Posologia \\
\hline 24 semanas 2 dias & 28,3 & 29,0 & - & - \\
\hline 25 semanas 2 dias & 28,1 & 25,9 & 10.000 & $12 / 12$ \\
\hline 26 semanas 2 dias & 28,1 & 28,7 & 10.000 & $12 / 12$ \\
\hline 26 semanas 3 dias & 27,5 & 35,5 & 10.000 & $8 / 8$ \\
\hline 26 semanas 5 dias & 27,8 & 36,7 & 10.000 & $8 / 8$ \\
\hline 27 semanas 2 dias & 27,0 & 27,9 & 10.000 & $8 / 8$ \\
\hline 27 semanas 3 dias & 28,9 & 45,6 & 12.000 & $8 / 8$ \\
\hline 28 semanas 3 dias & 29,9 & 42,1 & 12.000 & $8 / 8$ \\
\hline 29 a 38 semanas & 24,6 a 29,9 & 36,9 a 62,3 & 12.000 & $8 / 8$ \\
\hline
\end{tabular}

Após a $29^{a}$ semana a dose de heparina foi mantida em 12.000 UI cada 8 horas e os exames variaram na faixa descrita 
bro do tempo controle ${ }^{15}$. Durante a gravidez ocorre resistência à ação da heparina, o que ficou evidente neste caso, em que foi necessário aumentar a dose e diminuir os intervalos da heparina para manter o INR em 2 (Tabela I).

O parto vaginal parece ser a via de eleição, pois o risco de sangramento no parto cesariano é maior, bem como a duração do estresse e das alterações endócrino-metabólicas e imunológicas, o que poderia resultar em risco aumentado de eventos trombóticos ${ }^{15}$.

Contudo, o estresse do trabalho de parto desencadeia resposta neuroendócrina e metabólica semelhante a do estresse cirúrgico, resultando em ativação do eixo hipotálamo-hipofisário e conseqüente estado de hipercoagulabilidade 17-19. Portanto, a escolha da técnica anestésica neste caso deve objetivar, além do conforto materno e bem estar fetal, a atenuação da resposta ao do estresse do trabalho de parto. Sabe-se que a analgesia por via espinal é mais eficiente em atenuar resposta neuroendócrina e metabólica ao parto que a analgesia por via sistêmica ${ }^{20,21}$, justificando a escolha da técnica de analgesia peridural com infusão contínua. Os mecanismos pelos quais os bloqueios espinais modulam o estado de coagulação não estão bem definidos; porém, outros fatores que não a diminuição da resposta neuroendócrina ao estresse materno estão envolvidos. Dentre eles, estão: o aumento do fluxo sangüíneo na região bloqueada ${ }^{22}$, o aumento da atividade fibrinolítica ${ }^{23}$ via prevenção do aumento do fator inibidor do plasminogênio plasmático ${ }^{19}$ e a diminuição da adesividade plaquetária e da viscosidade sangüínea. Por outro lado, outros fatores envolvidos no estado de hipercoagulabilidade, tais como o aumento das interleucinas 1 , interleucinas 6 e do fator de necrose tumoral ${ }^{24}$, não sofrem influência das diversas técnicas de analgesia de parto atualmente empregadas.

Quando a paciente entra em trabalho de parto, a heparina deve ser suspensa, pois o risco de sangramento e de emergências hemorrágicas fica aumentado. Geralmente, o bloqueio do neuroeixo pode ser realizado, respeitando um tempo mínimo entre quatro a seis horas entre a última dose de heparina e a realização da punção lombar, desde que os exames apresentem parâmetros de normalidade. Neste caso, a heparina foi suspensa 8 horas antes de realizar a punção peridural, tempo suficiente para normalizar o TTPA.

A técnica de infusão inicial em bolus seguido por infusão contínua foi escolhida com o intuito de se obter analgesia intensa e constante, diminuindo a dose total de anestésicos e a resposta ao estresse do parto. A profilaxia de tromboembolismo com heparina deve ser re-introduzida no período pós-parto; no entanto, o cateter peridural deve ser retirado antes do início da profilaxia, pois sua retirada pode levar a hematoma peridural em paciente heparinizados. Estudos mostraram quea heparinização pode ser reiniciada com segurança uma hora após a passagem de cateter peridural, e provavelmente o mesmo intervalo de tempo deve ser respeitado na retirada do cateter $^{25}$

\section{Labor Analgesia in Protein S Deficient Patient. Case Report}

Renato Mestriner Stocche, TSA, M.D.; Luis Vicente Garcia, TSA, M.D.; Marlene Paulino dos Reis, M.D.; Jyrson Guilherme Klamt, TSA, M.D.

\section{INTRODUCTION}

Protein $\mathrm{S}$ is a serum glycoprotein dependent on vitamin $\mathrm{K}$, which acts as co-factor of protein $\mathrm{C}$, which has anticoagulant activity ${ }^{1}$. Protein $\mathrm{C}$ acts by inactivating coagulation cascade factors $\mathrm{Va}$ and $\mathrm{VIIIa}{ }^{2}$. This anticoagulant regulating effect presents as a physiological anti-thrombotic mechanism. So, protein $\mathrm{S}$ and/or protein $\mathrm{C}$ deficiency, are risk factors for thromboembolic events and are currently classified as thrombophilic diseases ${ }^{3}$.

Protein $\mathrm{S}$ deficiency may be inherited, with pattern varying from genetic to acquired changes ${ }^{4}$. Physiological states, such as pregnancy, may decrease plasma protein S levels ${ }^{5}$. Several diseases have been related to this deficiency, such as multiple myeloma ${ }^{6}$, HIV $^{7}$ and varicella ${ }^{8}$ virus infection, systemic lupus erythematosus ${ }^{9}$, and nephrotic syndrome ${ }^{10}$, among others.

In general, young protein S deficient patients present with recurrent venous or arterial thrombosis without predisposing factors or in less common sites for their age ${ }^{11-13}$. During pregnancy, there may be repetition abortion, abruption placenta, intra-uterine death and low gestational age weight, all related to multiple placental infarctions ${ }^{14}$. Diagnosis is suspected through history of thromboembolic events, familial history or abrupt pregnancy interruption history ${ }^{15}$. Confirmation is obtained by serum dosage ${ }^{16}$.

This report aimed at addressing coagulation management, thromboembolism and spinal hematoma risks associated to labor analgesia technique in inherited protein $\mathrm{S}$ deficient patient.

\section{CASE REPORT}

Pregnant patient, 29 years old, with protein S deficiency diagnosed by clinical and lab exams 2 years after presenting lower limbs deep vein thrombosis.

As from the $25^{\text {th }}$ week of gestation, patient was referred to the high risk and hematology outpatient department for follow up, when she presented the following lab results: $\mathrm{PT}=0.9 \mathrm{sec}-$ onds; INR = 0.9; TTPA = 32 seconds (control 26.6); TT = 8 seconds (control 9.5); Protein S $=35 \%$ (normal $=70 \%$ to $130 \%$ ); Antithrombin III $=90 \%$ (normal $=70 \%$ to $130 \%$ ); Fibrinogen $=$ $290 \mathrm{mg} / \mathrm{dl}$ (normal = 200 to 400); Protein C = 73\% (normal = $70 \%$ to $130 \%$ ). As from beginning of prenatal follow-up, she received 10,000 to $12,000 \mathrm{IU}$ subcutaneous heparin every 12 or 8 hours to maintain INR close to 2 (Table I). Hematological exams with hemoglobin and hematocrit count, among others, have remained within normal ranges throughout pregnancy and in the immediate post-delivery period. 


\begin{tabular}{|c|c|c|c|c|}
\hline Amenorrhea Time & TTPA Control & TTPA Patient & Heparin Dose & Administration \\
\hline 24 weeks 2 days & 28.3 & 29.0 & - & - \\
\hline 25 weeks 2 days & 28.1 & 25.9 & 10000 & $12 / 12$ \\
\hline 26 weeks 2 days & 28.1 & 28.7 & 10000 & $12 / 12$ \\
\hline 26 weeks 3 days & 27.5 & 35.5 & 10000 & $8 / 8$ \\
\hline 26 weeks 5 days & 27.8 & 36.7 & 10000 & $8 / 8$ \\
\hline 27 weeks 2 days & 27.0 & 27.9 & 10000 & $8 / 8$ \\
\hline 27 weeks 3 days & 28.9 & 45.6 & 12000 & $8 / 8$ \\
\hline 28 weeks 3 days & 29.9 & 42.1 & 12000 & $8 / 8$ \\
\hline 29 to 38 weeks & 24.6 to 29.9 & 36.9 to 62.3 & 12000 & $8 / 8$ \\
\hline
\end{tabular}

After the $29^{\text {th }}$ week, heparin dose was maintained in 12,000 Ul every 8 hours and tests have varied within the described range

Pregnancy has evolved without severe events and with controlled coagulopathy. Four ultrasounds were performed and have not evidenced fetal or placental abnormalities.

With 38 weeks and 6 days of amenorrhea, patient was admitted in labor with $4 \mathrm{~cm}$ dilatation and dynamic of 2 contractions in 10 minutes. After admission, the case was discussed with hematologist, anesthesiologist and obstetrician who decided to withdraw heparin and administer protamine if necessary. The option has been vaginal delivery with early delivery epidural analgesia. After previous activated coagulation time test resulting in 105 seconds and TTPA close to control (25.6 seconds) epidural puncture and catheter insertion were performed. Initial $6 \mathrm{ml}$ of $0.2 \%$ bupivacaine associated to $20 \mu \mathrm{g}$ fentanyl were administered followed by $0.2 \%$ bupivacaine and fentanyl $\left(1 \mu \mathrm{g} \cdot \mathrm{ml}^{-1}\right)$ continuous infusion until second labor stage completion, with no need for additional doses. Delivery was helped by forceps 1 hour after total cervical dilatation. Total infusion time was 5 hours, with total $40 \mathrm{mg}$ bupivacaine and $34 \mu \mathrm{g}$ fentanyl doses. Epidural catheter was removed immediately after delivery and, 1 hour later, 10,000 IU subcutaneous heparin were restarted every 12 hours. Patient and neonate evolved without postoperative complications and were discharged 3 days after delivery.

\section{DISCUSSION}

Protein $S$ deficiency associated to gestational hypercoagulability and labor stress highly increases the risk for intravascular thrombosis during pregnancy and in the peri-delivery period, thus requiring thromboembolism prophylaxis ${ }^{14,15}$. Heparin poses less fetal risk as compared to cumarin agents and should be used throughout pregnancy and in the immediate post-delivery period. In our case, and according to the literature, TTPA was twice the control time ${ }^{15}$. There is heparin action resistance during pregnancy and this was apparent in our case where heparin dose had to be increased and intervals decreased to maintain INR in 2 (Table I). Vaginal delivery seems to be the method of choice because bleeding risk in C-section is higher, as well as stress and en- docrine-metabolic and immune changes duration, which could result in increased risk for thrombotic events ${ }^{15}$. However, labor stress triggers neuroendocrine and metabolic response similar to surgical stress, resulting in hypothalamohypophysial axis activation and consequent hypercoagulability ${ }^{17-19}$. So, anesthetic technique in this case should aim at maternal comfort and fetal wellbeing in addition to attenuating labor stress response. It is known that spinal analgesia is more effective in attenuating neuroendocrine and metabolic response to labor than systemic analgesia 20,21 , justifying the choice of epidural analgesia with continuous infusion. Mechanisms by which spinal blocks modulate coagulation are not well defined; however other factors, different from neuroendocrine response decrease to maternal stress, are involved, including: increased blood flow in the blocked region ${ }^{22}$, increase in fibrinolytic activity ${ }^{23}$ via prevention of plasma plasminogen inhibiting factor increase ${ }^{19}$ and decrease in platelet aggregation and blood viscosity. On the other hand, other factors involved in hypercoagulability, such as increased IL1, IL6 and tumor necrosis factor ${ }^{24}$, are not influenced by current labor analgesic techniques.

Heparin should be withdrawn during labor because the risk for bleeding and hemorrhagic emergencies is increased. In general, neuraxis may be blocked respecting a minimum interval of 4 to 6 hours between last heparin dose and lumbar puncture, provided exams are within normal ranges. In our case, heparin was withdrawn 8 hours before epidural puncture, which was enough to normalize TTPA.

Initial bolus infusion followed by continuous infusion was the technique of choice to obtain deep and constant analgesia, decrease total anesthetic dose and labor stress response. Thromboembolism prophylaxis with heparin should be reintroduced in the post-delivery period; however, epidural catheter should be removed before starting prophylaxis because its removal may lead to epidural hematoma in patients receiving heparin. Studies have shown that heparin may be safely restarted one hour after epidural catheter insertion and it is possible that the same time interval should be respected for catheter removal $^{25}$. 


\section{REFERÊNCIAS - REFERENCES}

01. Yamazaki T - Molecular biological analysis of hereditary thrombophilia-genetic characterization of protein S deficiency. Rinsho Ketsueki, 1995;36:299-302.

02. Dahlbäck B, Wiedmer T, Sims PJ - Binding of anticoagulant vitamin K-dependent protein $S$ to platelet-derived microparticles. Biochemistry, 1992;31:12769-12777.

03. Faioni EM, Valsecchi C, Palla A et al - Free protein S deficiency is a risk factor for venous thrombosis. Thromb Haemost, 1997; 78:1343-1346.

04. Formstone CJ, Wacey AI, Berg LP et al - Detection and characterization of seven novel protein S (PROS) gene lesions: evaluation of reverse transcript-polymerase chain reaction as a mutation screening strategy. Blood, 1995;86:2632-2641.

05. Lefkowitz JB, Clarke SH, Barbour LA - Comparison of protein S functional and antigenic assays in normal pregnancy. Am J Obstet Gynecol, 1996;175:657-660.

06. Deitcher SR, Erban JK, Limentani AS - Acquired free protein S deficiency associated with multiple myeloma: a case report. Am J Hematol, 1996;51:319-323.

07. Sugerman RW, Church JA, Goldsmith JC et al - Acquired protein $S$ deficiency in children infected with human immunodeficiency virus. Pediatr Infect Dis J, 1996;15:106-111.

08. Levin M, Eley BS, Louis $\mathrm{J}$ et al - Postinfectious purpura fulminans caused by an autoantibody directed against protein S. J Pediatr, 1995;127:355-363.

09. Ginsberg JS, Demers C, Brill Edwards P et al - Acquired free protein $\mathrm{S}$ deficiency is associated with antiphospholipid antibodies and increased thrombin generation in patients with systemic lupus erythematosus. Am J Med, 1995;98:379-383.

10. Hanevold CD, Lazarchick J, Constantin MA et al - Acquired free protein $\mathrm{S}$ deficiency in children with steroid resistant nephrosis. Ann Clin Lab Sci, 1996;26:279-282.

11. Simioni $P$, Sanson BJ, Prandoni $P$ et al - Incidence of venous thromboembolism in families with inherited thrombophilia. Thromb Haemost, 1999;81:198-202.

12. Ganesan V, McShane MA, Liesner R et al - Inherited prothrombotic states and ischaemic stroke in childhood. J Neurol Neurosurg Psychiatry, 1998;65:508-511.

13. Siqueira Neto JI, Santos AC, Fábio SR et al - Cerebral infarctions in young patients related to deficiency of natural anticoagulants. Protein $\mathrm{C}$ and protein S. Arq Neuropsiquiatr, 1996;54:590-594.

14. Arias F, Romero R, Joist $\mathrm{H}$ et al - Thrombophilia: a mechanism of disease in women with adverse pregnancy outcome and thrombotic lesions in the placenta. J Matern Fetal Med, 1998;7: 277-286.

15. Bonnar J, Green R, Norris L - Inherited thrombophilia and pregnancy: the obstetric perspective. Semin Thromb Hemost, 1998;24:(Suppl1):49-53.

16. Tripodi A, Bertina RM, Conard J et al - Multicenter evaluation of three commercial methods for measuring protein $S$ antigen. Thromb Haemost, 1992;68:149-154.

17. Rosenfeld BA, Beattie C, Christopherson R et al - The perioperative ischemia randomized anesthesia trial study group: the effects of different anesthetic regimens on fibrinolysis and development of postoperative arterial thrombosis. Anesthesiology, 1993;79:435-443.
18. Breslow MJ, Parker SD, Frank SM et al - Determinants of catecholamine and cortisol response to lower-extremity revascularization. Anesthesiology, 1993;79:1202-1209.

19. Rosenfeld BA, Faraday N, Campbell D et al - Hemostatic effects of stress hormone infusion. Anesthesiology, 1994;81: 1116-1126.

20. Hoffmann R - The thrombo-embolic risk in surgery. Hepatogastroenterology, 1991;38:272-278.

21. Liu S, Carpenter RL, Neal JM - Epidural anesthesia and analgesia: their role in postoperative outcome. Anesthesiology, 1995;82:1474-1505.

22. Modig J, Malberg P, Karlstrom G - Effect of peridural versus general anaesthesia on calf blood flow. Acta Anaesthesiol Scand, 1980;24:305-309.

23. Donadoni R, Baele G, Devulder J et al - Coagulation and fibrinolytic parameters in patients undergoing total hip replacement: Influence of anaesthesia technique. Acta Anaesthesiol Scand, 1989;33:588-589.

24. Bateman A, Singh A, Kral T et al - The immune-hypothalamic-pituitary-adrenal axis. Endocrine Rev, 1989;10:92-112.

25. Rao TLK, El-Etr AA - Anticoagulation following placement of epidural and subarachnoid catheters: an evaluation of neurologic sequelae. Anesthesiology, 1981;55:293-296.

\section{RESUMEN}

Stocche RM, Garcia LV, Reis MP, Klamt JG - Analgesia de Parto en Paciente Portadora de Deficiencia de Proteína S. Relato de Caso

JUSTIFICATIVA Y OBJETIVOS: En la deficiencia de proteína $S$, una glucoproteína con actividad anticoagulante, el riesgo de eventos tromboembólicos está aumentado. El objetivo de este relato es abordar el manoseo anestésico en paciente obstétrica portadora de esta deficiencia.

RELATO DE CASO: Paciente con deficiencia de proteína S, con 25 semanas de gestación, presentó los siguientes resultados de exámenes: INR =0,9, TTPA = $32 \mathrm{~s}$ (control 25, 6), proteína $S=35 \%$ (normal $=70 \%$ a 130\%). En los dos últimos trimestres de embarazo, hizo uso de hasta $12000 \mathrm{U}$ de heparina, cada 8 horas. Con 38 semanas, fue internada en trabajo de parto. Pasadas 8 horas de la interrupción de la heparina, y ya con TTPA 25,8 s (control 27,8 s), se realizó anestesia peridural con inyección de $6 \mathrm{ml}$ de bupivacaína a $0,2 \%$ y fentanil $(20 \mu \mathrm{g})$, seguido de infusión continua. EL tiempo de infusión fue de 5 horas con dosis total de $40 \mathrm{mg}$ de bupivacaína. No hubo intercurrencias y, 1 hora después de la retirada del catéter, fue reiniciada heparina, por vía subcutánea, 10.000 UI, a cada 12 horas. La madre y el recién nacido evoluyeron bien, recibiendo alta en el tercero día del pos-parto.

CONCLUSIONES: Embarazadas con deficiencia de proteína S deben recibir anticoagulantes con el objetivo de mantener el TTPA 2 veces el valor control. La heparina, por no atravesar a barrera placentaria, es el anticoagulante de elección en obstetricia. El bloqueo puede ser realizado respetando un tiempo mínimo entre cuatro a seis horas entre a última dosis de heparina y la realización de la punción lumbar, desde que los exámenes presenten parámetros de normalidad. Entretanto, en estos casos, la analgesia peridural puede auxiliar en la profilaxis de eventos tromboembólicos. 